\title{
Soil compaction and chestnut ink disease
}

\author{
By T. F. Fonseca ${ }^{1,2}$, C. G. Abreu ${ }^{1}$ and B. R. Parresol ${ }^{3}$ \\ ${ }^{1}$ Centro de Estudos em Gestão de Ecossistemas/Departamento Florestal, Universidade de Trás-os- \\ Montes e Alto Douro, Apartado 1013, 5001-911 Vila Real, Portugal; ${ }^{2} E$-mail: tfonseca@utad.pt \\ (for correspondence); ${ }^{3}$ USDA Forest Service, Southern Research Station, Asheville, NC, USA
}

\begin{abstract}
Summary
Chestnut ink disease caused by the oomycete Phytophthora cinnamomi, a soil-borne pathogen of world-wide distribution, accounts for the majority of disease problems on chestnuts in Portugal, limiting yield in a large number of stands and impeding establishment of trees in new areas. A survey was carried out in 32 chestnut stands in the Padrela Mountains of northern Portugal to investigate the relationship among ink disease occurrence, edaphic factors and management practices. A logistic regression function was employed to analyze the effect of soil attributes and management practices on the stand health status. Results showed that the main factors affecting disease were soil compaction (COMP), soil organic matter level (OM) and manuring practice (MA). A logistic model containing the soil variable COMP and the interaction term $\mathrm{OM} \times$ MA correctly predicted the stand health status in $94 \%$, or 30 , of the 32 stands studied. The logistic function coefficients indicate that the probability of a stand having ink disease increases with increasing soil compaction and increasing soil organic matter content in stands where manuring is the usual practice.
\end{abstract}

\section{Introduction}

The oomycete Phytophthora cinnamomi Rands, a well known soil-borne pathogen of mainly woody hosts, was probably introduced into Europe early in the nineteenth century from the Pacific Celebes - New Guinea region (Brasier 1996). According to Zentmyer (1980), one of the early identifications of this pathogen on chestnuts affected by ink disease was made in 1942 in Portugal. Initially, restricted to chestnut trees in the northeastern part of the country (Pimentel 1947), this aggressive root pathogen is today widely distributed across Portugal and occurs on other hosts, especially cork oaks (Brasier et al. 1993; BRASIER 1996). Although P. cambivora has been occasionally isolated from chestnut tissue in the past, $P$. cinnamomi is by far the most prevalent species in chestnut orchards and nurseries in northeastern Portugal (Martins et al. 1999). The oomycete entered North America in the mid-1800's and caused the recession of American chestnut (Castanea dentata (Marsh.) Borkh.) from large areas in the Gulf and Atlantic states in the United States prior to 1900 (ANAGNOSTAKIs 1995). The pathogen causes brownish-black lesions on the roots that exude an inky-blue stain, hence the name ink disease. Trees die when the root collar is girdled, or when most of the roots are killed.

Weste (1984) reports for Australia that site interaction with host and pathogen is of overriding importance in determining the severity of the attacks due to Phytophthora. For Portugal, Portela et al. (1999) also report that several interacting factors predispose the trees to attack by this organism such as restrictions to root expansion, poor soil fertility, low aeration, and soil disturbance by tillage. The disease is a major threat to the sustainability of chestnut ecosystems in the northern part of Portugal (ABREu 1996), where many stands contain clusters of dead and dying trees interspersed with healthy trees. Individual trees exhibit root-rot, necrotic inner bark lesions in the collar region and general 
dieback. Epicormic shoots, which form along the trunk after the loss of most of their foliage, wilt and eventually die. In summer, some trees may die suddenly with brown leaves and burrs attached to their branches while others remain alive in a declining condition for several years.

Portugal is the third largest producer of chestnut fruits in Europe, producing around 20000 tons per year (BODET 2001; Bounous 2002) of which 4500-9000 tons are exported. Chestnuts, needless to say, are economically important to local economies. International chestnut prices have increased consistently over the last 20 years, driving the interest in chestnut production. In northern Portugal, chestnut trees are grown from 600 to $1000 \mathrm{~m}$ a.s.l. in mountainous areas, with rye and potatoes as understorey crops. The soils are usually shallow with high acidity and low organic matter content, as well as extractable phosphorus and exchangeable bases. Soil compaction and root damage from wheel traffic and equipment associated with tillage are common. The increased demand for chestnuts has been satisfied by expanding the number of hectares in production, increasing the use of nitrogen to boost output per hectare, and intensifying management practices such as manuring (Portela et al. 2003). However, the severity of ink disease has caused considerable dieback in chestnut groves.

There have been many attempts to control ink disease, through biological control using ectomycorrhizal fungi (BRANzANTI et al. 1998), and grafting C. sativa onto ink-disease resistant rootstocks (CRADDOCK and BASSI 1999). However, such control measures are expensive and difficult to apply. Portela et al. (1999) suggested to control factors that predispose the trees to attack. The purpose of this study was to identify easily controllable edaphic factors and management practices that contribute to the risk of ink disease in chestnut groves in northern Portugal.

\section{Material and methods}

\subsection{Data}

This study is based on a regional chestnut ink disease survey in 32 stands from northern Portugal, 18 plots with different levels of disease damage and 14 plots without any disease symptoms (Table 1). These stands were selected in previous surveys in the Padrela mountainous region where the disease is widespread and $P$. cinnamomi had been frequently isolated using selective agar media such as the pimaricin-vancomycin PCNB (pentachloronitrobenzene) medium of Tsao and Ocana (1969), as well as the blue lupin baiting method of MARKs et al. (1972) for isolation from damaged feeder roots and soils (ABrEu et al. 1993, 1999). Tree collar with irregular wedge-shaped necrosis from dying trees with epicormic shoots were also used for isolation by removing the depressed bark and plating samples on selective media as mentioned.

The identity of $P$. cinnamomi was presented in a previous project from 1993 to 1999 and based on morphological characters, colony type and pathogenicity to wild chestnut seedlings, as well as electrophoresis of mycelial proteins and isozyme patterns of selected isolates. Isolates with dubious classification, were identified by the International Mycological Institute (Surrey, UK; Abreu et al. 1999).

Damage was assessed on crown defoliation and leaf discoloration of 25 trees selected in each stand following a spiral from the plot center and using standardized criteria (EC guideline 1696/87) and keys (CADAHIA et al. 1991): $0=$ healthy $(0-10 \%), 1=$ slightly damaged $(11-25 \%), 2=$ moderately damaged $(26-60 \%), 3=$ severely damaged $(61-90 \%)$ and $4=$ dying. Data recorded include altitude, slope, physical soil attributes (soil compaction, depth, texture) and chemical soil attributes (organic matter, $\mathrm{pH}$, extractable phosphorus, potassium and base saturation). Soil compaction was determined using cone 
penetrometers under the projection of chestnut crowns. Twenty measurements were made below the crowns of five trees per stand, and defined as synonymous to penetrometer resistance (BENGOUGH and Mullins 1990); effective soil depth and texture were described according to FAO-ISRIC guidelines. Soil organic matter was determined by oxidation following the modified Walkley-Black method, $\mathrm{pH}$ measured with a $1: 25$ soil solution ratio, extractable phosphorus and potassium were determined by ammonium lactate at $\mathrm{pH}$ 3.6 extraction and the exchangeable bases were extracted with $1 \mathrm{~N}$ ammonium acetate at $\mathrm{pH} 7$ and the exchangeable acidity $\left(\mathrm{H}^{+}+\mathrm{Al}^{3+}\right)$ by the $1 \mathrm{~N} \mathrm{KCl}$ method. Farmers were asked about management practices over the last 3 years, particularly pruning, manuring and fertilizing. Except for pruning, the application of these practices is normally done annually or biennially.

\subsection{Analysis}

An appropriate methodology for analyzing binary response data is the logistic model (NeTER et al. 1996). For this study, we assigned $Y=1$ if chestnut ink disease was present in the stand (from slight to severe in Table 1), otherwise $Y=0$. Let $p$ be the probability that a plot has ink disease, that is, the probability that $Y=1$. The logistic regression model uses the logit of $p$ as the dependent variable where

The logistic model is:

$$
\operatorname{logit}(p)=\ln \left(\frac{p}{1-p}\right)
$$

$$
\operatorname{logit}(p)=\beta_{0}+\beta_{1} X_{1}+\cdots+\beta_{k} X_{k}+\varepsilon
$$

where the $X$ 's are independent variables, the $\beta$ 's are model parameters (usually estimated by maximum likelihood procedures) and $\varepsilon$ is the error term. The independent variables may be quantitative or may be qualitative and represented by dummy variables. In the logistic regression model, an interpretation of the $i$ th (where $i=1,2, \ldots, k$ ) estimated regression coefficient $\hat{\beta}_{i}$ may be found in the property that the estimated odds $\hat{p} /(1-\hat{p})$ is multiplied by $\exp \left(\hat{\beta}_{i}\right)$ for any unit increase in the variable $X_{i}$, assuming that all other predictor variables are held constant (NETER et al. 1996). The accuracy of classification by a logistic model is measured by the ability to correctly predict the observed events and the nonevents, for a given cut off probability (usually set at $p=0.5$ ).

\subsubsection{Variable selection}

A stepwise variable selection procedure (SAS PROC LOGISTIC with the model selection option STEPWISE) was used to determine which edaphic factors and management practices were related to stand health (SAS Institute INC. 1999). The pool of independent variables for possible inclusion in the logistic model were the physical and chemical soil attributes measured on each plot as well as the binary variables describing the management practices (see Table 1).

\subsubsection{Model building}

The full model and several reduced models were analyzed and compared by the overall model likelihood ratio chi-square statistic, the individual parameter Wald chi-square tests of significance, the generalized $R^{2}$ statistic, and the model deviance statistic (Hosmer and Lemeshow 1989; Myers 1990; NagelKerke 1991; Neter et al. 1996). The generalized $R^{2}$ statistic for logistic regression (NAGELKERKE 1991) is $R^{2}=\left\{1-[L(0) / L(\beta)]^{2 / n}\right\} /$ $\left\{1-[L(0)]^{2 / n}\right\}$, where $L(0)$ is the likelihood of the intercept-only model, $L(\beta)$ is the 


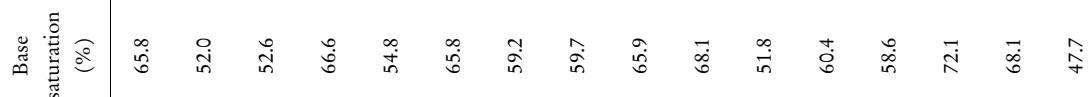

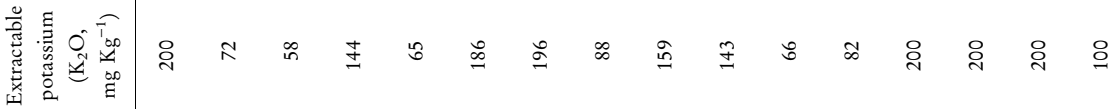

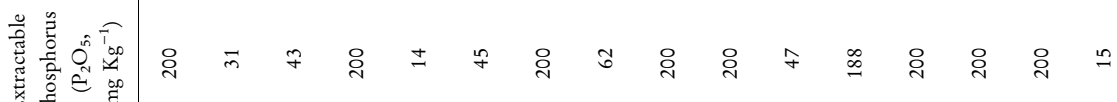

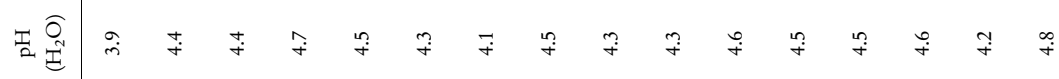

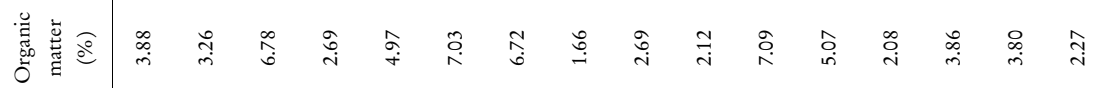

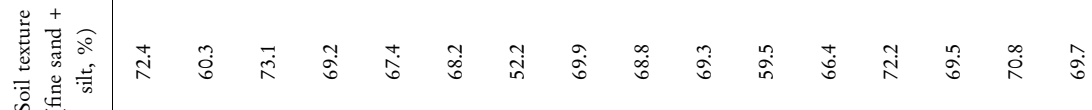

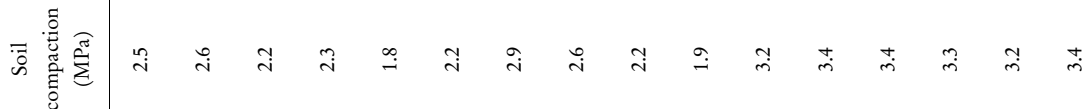
" 䓈

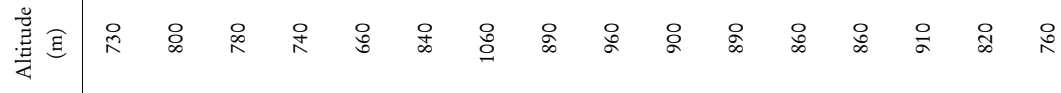

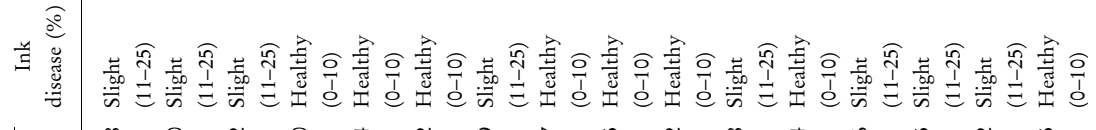

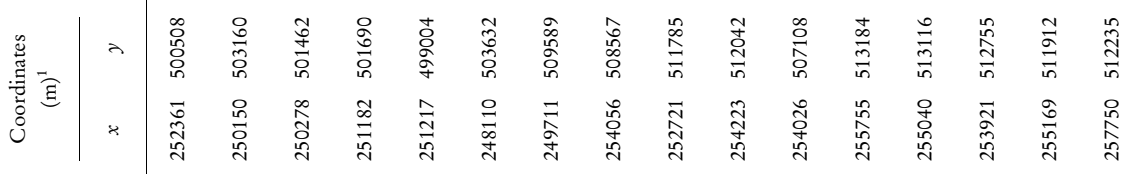

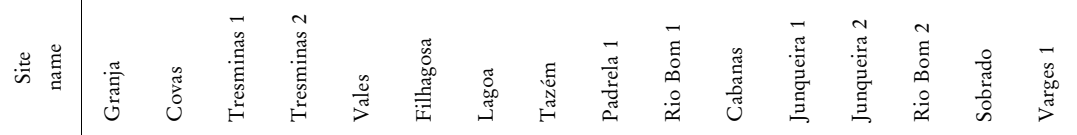

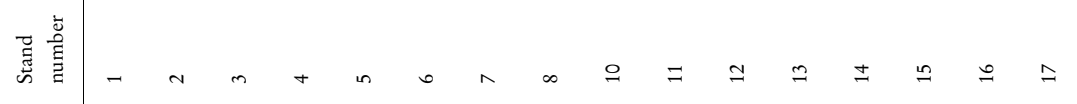




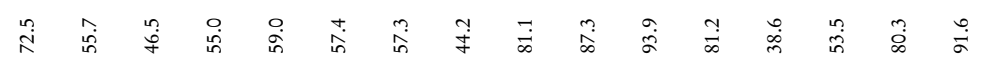

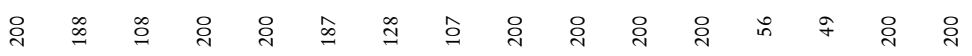
กำ

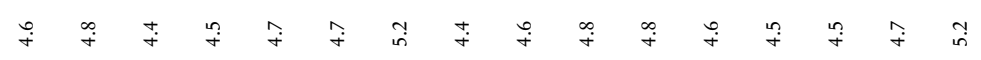
तु

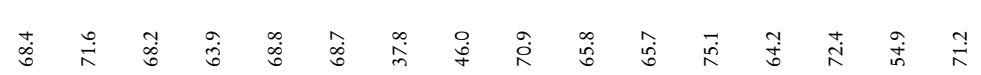

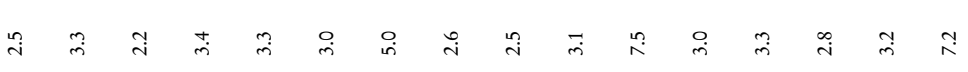

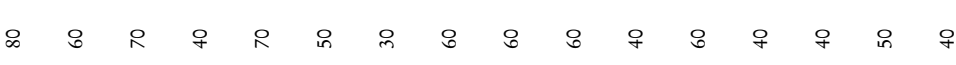
4 3

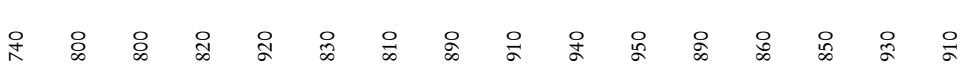

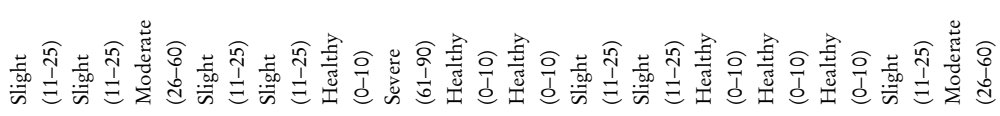

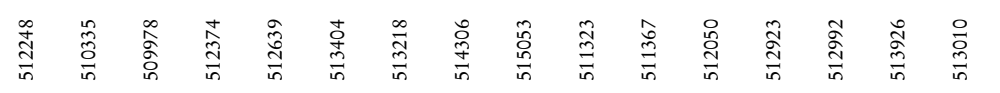

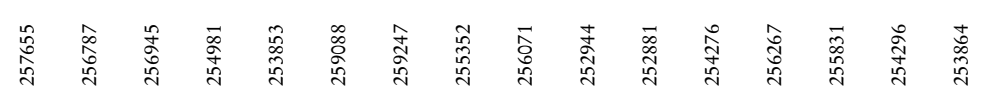

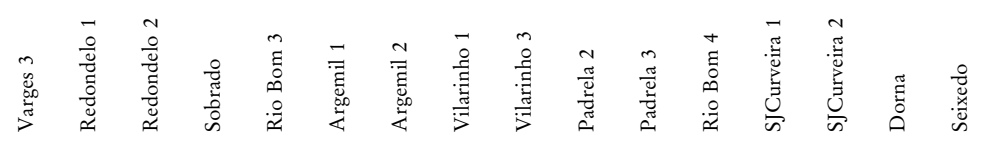
ㅇำ 
likelihood of the specified model, and $n$ is the sample size. The model deviance statistic (Hosmer and Lemeshow 1989), denoted by $D$, is a measure of discrepancy between observed and fitted values. The Akaike information Criterion (AIC) and Schwartz Criterion (SC) statistics were used for comparing the alternative models, lower values indicating a better model (SAS InstiTUTE INC. 1999). In addition, the classification table shows the accuracy of the proposed models for a cut off probability of $p=0.5$.

\section{Results}

\subsection{Model selection}

Statistical analysis using the stepwise selection procedure showed that the set of variables most related to disease occurrence were soil compaction (COMP), organic matter content $(\mathrm{OM})$, and manuring practice (MA). All others variables were not retained by the stepwise selection procedure in the logistic model, and were therefore, not considered for further analysis.

To ascertain the influence of the individual potential explanatory variables identified, simple regression models were investigated (not shown). The likelihood ratio chi-square statistic for the single-response models based on COMP and on MA provided evidence against the null hypothesis that the coefficients were equal to zero $(\mathrm{p}<0.0500)$. In contrast, the same statistic was found not significant when used to test the single effect of OM $(\mathrm{p}=0.3521)$. These preliminary results suggested that an interaction effect is present. Therefore, five alternative logistic response functions were tested:

$$
\begin{gathered}
\operatorname{logit}(p)=\beta_{0}+\beta_{1} \mathrm{COMP}+\beta_{2} \mathrm{OM}+\beta_{3} \mathrm{MA}+\beta_{4}(\mathrm{OM} \times \mathrm{MA})+\varepsilon \\
\operatorname{logit}(p)=\beta_{0}+\beta_{1} \mathrm{COMP}+\beta_{2} \mathrm{OM}+\beta_{3} \mathrm{MA}+\varepsilon \\
\operatorname{logit}(p)=\beta_{0}+\beta_{1} \mathrm{COMP}+\beta_{2}(\mathrm{OM} \times \mathrm{MA})+\varepsilon \\
\operatorname{logit}(p)=\beta_{0}+\beta_{1} \mathrm{COMP}+\beta_{2} \mathrm{OM}+\varepsilon \\
\operatorname{logit}(p)=\beta_{0}+\beta_{1} \mathrm{COMP}+\beta_{2} \mathrm{MA}+\varepsilon
\end{gathered}
$$

$p$ is the probability of a stand having chestnut ink disease, COMP is soil compaction, OM is organic matter, MA is a binary variable for the effect of manuring. Equation (3) represents the full model and Eqs (4)-(7) define reduced models.

The likelihood ratio chi-square statistic for the five alternative models provided evidence against the null hypothesis that all response coefficients were equal to zero (Full model (3) $\chi^{2}=35.01, \mathrm{p}<0.0001$; model (4) $\chi^{2}=21.33, \mathrm{p}<0.0001$; model (5) $\chi^{2}=26.48$, $\mathrm{p}<0.0001$; model (6) $\chi^{2}=9.49, \mathrm{p}=0.0087$; model (7) $\left.\chi^{2}=14.64, \mathrm{p}=0.0007\right)$. None of the models showed lack of fit according to the value of the deviance statistic (Full model (3) $D=8.85, \mathrm{p}=0.99$; model (4) $D=22.53, \mathrm{p}=0.76$; model (5) $D=14.60, \mathrm{p}=0.98$; model (6) $D=34.37, \mathrm{p}=0.23$; model (7) $D=14.99, \mathrm{p}=0.66$ ).

Despite these overall good results, parameter estimates for the full model were not significant at the $5 \%$ level, according to the Wald chi-square test (Table 2), indicating that some independent variables in the full model were correlated. The effect of organic matter was not significant either alone, or together with the variable COMP $[\mathrm{p}=0.1070$, see Table 2, Eq. (6)], The organic matter content was correlated with manuring. Hence, a choice had to be made between the other three candidate models (4), (5) and (7) using the AIC and SC criteria and the classification table. The criteria values 
Table 2. Parameter estimates for five logistic models of ink disease probability

\begin{tabular}{|c|c|c|c|c|c|c|c|c|c|c|}
\hline \multirow[b]{2}{*}{ Variable } & \multicolumn{2}{|c|}{ Full model (3) } & \multicolumn{2}{|c|}{ Model (4) } & \multicolumn{2}{|c|}{ Model (5) } & \multicolumn{2}{|c|}{ Model (6) } & \multicolumn{2}{|c|}{ Model (7) } \\
\hline & Estimates & $\begin{array}{c}\mathrm{p}^{-} \\
\text {values }\end{array}$ & Estimates & $\begin{array}{c}\mathrm{p}^{-} \\
\text {values }\end{array}$ & Estimates & $\begin{array}{c}\mathrm{p}^{-} \\
\text {values }^{1}\end{array}$ & Estimates & $\begin{array}{c}\mathrm{p}^{-} \\
\text {values }\end{array}$ & Estimates & $\begin{array}{c}\mathrm{p}^{-} \\
\text {values }\end{array}$ \\
\hline Intercept & -2.2467 & 0.7630 & -13.7416 & 0.0081 & -9.4601 & 0.0126 & -6.4007 & 0.0262 & -6.5374 & 0.0162 \\
\hline COMP & 6.3496 & 0.2111 & 2.6025 & 0.0131 & 2.2637 & 0.0325 & 1.6928 & 0.0403 & 1.6483 & 0.0382 \\
\hline OM & -4.6558 & 0.1513 & 0.9285 & 0.0487 & & & 0.4103 & 0.1070 & & \\
\hline MA & -31.1097 & 0.1371 & 4.0733 & 0.0094 & & & & & 2.7728 & 0.0162 \\
\hline $\mathrm{OM} \times \mathrm{MA}$ & 10.2141 & 0.1102 & & & 1.2877 & 0.0087 & & & & \\
\hline \multicolumn{11}{|c|}{ Goodness of Fit Criterion } \\
\hline $\begin{array}{l}\text { Akaike } \\
\text { Information }\end{array}$ & \multicolumn{2}{|c|}{18.850} & \multicolumn{2}{|c|}{30.531} & \multicolumn{2}{|c|}{23.376} & \multicolumn{2}{|c|}{40.372} & \multicolumn{2}{|c|}{35.221} \\
\hline Schwartz & \multicolumn{2}{|c|}{26.850} & \multicolumn{2}{|c|}{36.394} & \multicolumn{2}{|c|}{27.773} & \multicolumn{2}{|c|}{44.769} & \multicolumn{2}{|c|}{39.618} \\
\hline
\end{tabular}

Table 3. Classification table for the logistic regression equations ${ }^{1}$

\begin{tabular}{|c|c|c|c|c|c|}
\hline \multirow[b]{2}{*}{ Model } & \multicolumn{2}{|c|}{ Correct } & \multicolumn{2}{|c|}{ Incorrect } & \multirow[b]{2}{*}{ Correct $(\%)$} \\
\hline & Event & Non-event & Event & Non-event & \\
\hline Full model (3) & 16 & 12 & 2 & 2 & 87.5 \\
\hline Model (4) & 15 & 12 & 3 & 2 & 84.4 \\
\hline Model (5) & 17 & 13 & 1 & 2 & 93.8 \\
\hline Model (6) & 15 & 7 & 3 & 7 & 68.8 \\
\hline Model (7) & 15 & 10 & 3 & 4 & 78.1 \\
\hline
\end{tabular}

(Table 2) and the classification table (Table 3) led to the acceptance of the reduced model (5) as the appropriate logistic model. All parameters in that model were significant at the $5 \%$ level (Table 2), and 30 of the 32 cases were correctly classified (Table 3 ) by the model.

\subsection{Model interpretation}

According to the model comparison results the proposed model is given by:

$$
\hat{p}=\frac{\exp [-9.4601+2.2637 \mathrm{COMP}+1.2877(\mathrm{OM} \times M A)]}{1+\exp [-9.4601+2.2637 \mathrm{COMP}+1.2877(\mathrm{OM} \times M A)]}
$$

where $\hat{p}$ is the estimated probability for a stand to evidence the disease. The shape of this fitted response function is shown in Fig. 1. The sign of the parameter estimate associated with the variable COMP is positive, as was expected. An increase in soil compaction increases the probability of disease. The estimated odds ratio for this variable is 9.6186 , which means that the odds increase by about 10 times for a stand to evidence the disease, with each additional unit of soil compaction, holding organic matter content and category of the manuring variable constant. 


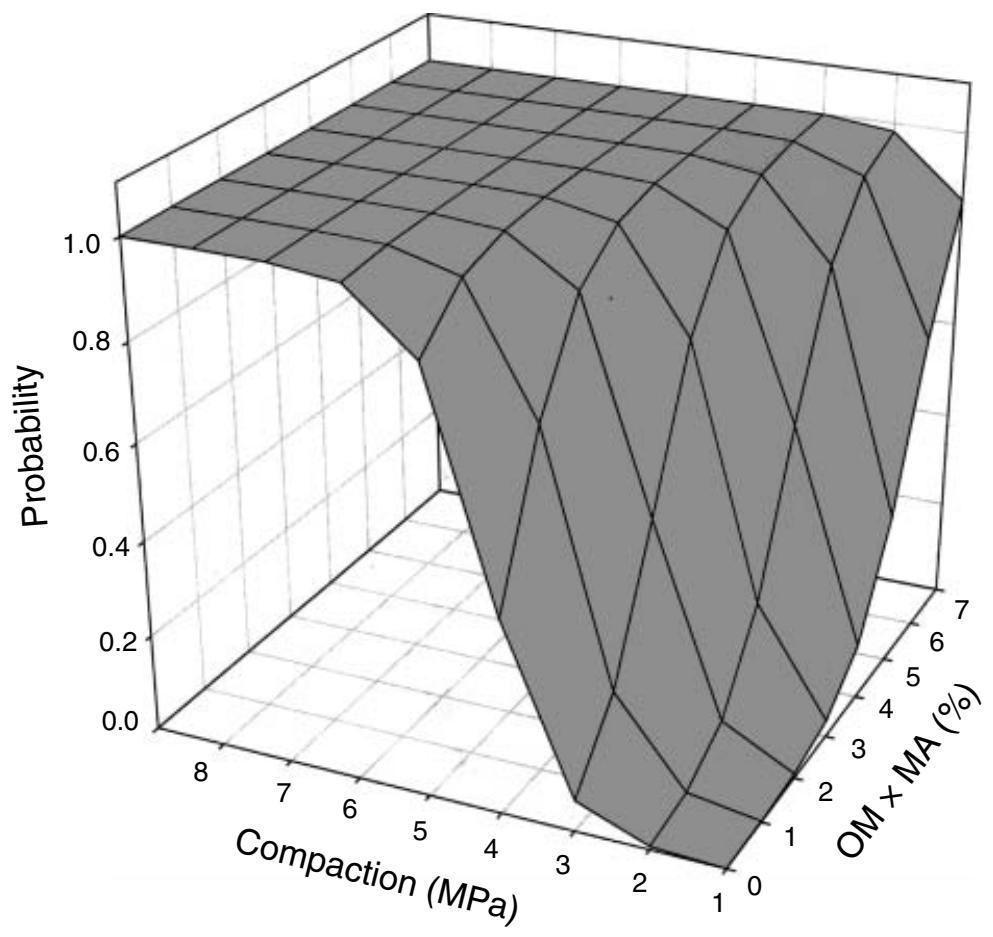

Fig. 1. Probability of a stand evidencing ink disease symptoms in relation to soil compaction (COMP) and the interaction between organic matter and manuring $(\mathrm{OM} \times \mathrm{MA})$

The interpretation of the interaction term is not straightforward, because $\exp \left(\hat{\beta}_{2}\right)$ can no longer be interpreted as the odds ratio. Given that MA is a binary variable that takes the value 1 or 0 , there are two response functions depending on the existence or absence of the manuring management practice. Both functions are increasing, as illustrated in Fig. 1, according to the positive sign of the parameter estimates associated with the effects. In presence of manuring $(\mathrm{MA}=1)$ the response function depends on the variables COMP and OM. The probability of disease increases with the values of these variables. In absence of manuring $(\mathrm{MA}=0)$ the probability of disease is no longer explained by the level of organic matter and only depends on the value of soil compaction.

\section{Discussion}

The developed logistic model pointed out two main aspects: a negative effect of soil compaction on tree health and, in presence of manuring, a rising probability of disease occurrence as the organic matter content increases. The other physical soil attributes (depth, texture) and chemical soil attributes $(\mathrm{pH}$, extractable phosphorus, potassium and base saturation) were found to be non-significant for the analyzed dataset. Likewise, altitude and slope seemed not to play a role for the occurrence of the disease. The two significant variables, soil compaction and the interaction term organic matter content $\times$ presence of manure, make sense based on theoretical knowledge and observational studies. 
Soil compaction from wheel traffic and equipment associated with tillage are usual in the study area. In infected stands such equipment could have a major effect in spreading the disease. Soil compaction restricts root growth and, as a consequence, makes trees more susceptible to root rotting fungi (YARHAM 1988). BRASIER (1996) reported that loss of fine roots, combined with drought, may favor P. cinnamomi activity and development. The present study shows the magnitude of this effect can be so pronounced that, as indicated by the logistic regression, the estimated odds of a chestnut stand displaying the disease increase almost 10 times with each additional unit of compaction, if the other variables are kept constant. COFFey (1987) refers to an effective innovation used in avocado farming of planting avocados on mounds. Mounding enhances aeration and drainage, promoting root development and reducing incidence of Phytophthora root-rot. This may be a viable procedure for chestnut orchards to prevent soil compaction and to favor root development (UTAD-DratM 1999).

Although the effects of management practices on dieback caused by $P$. cinnamomi have been reported for forest and agricultural systems (e.g. CASTELLO et al. 1995; Portela et al. 1999) the relationship between manuring and tree health is, for now, rather speculative. Results obtained by Kliejunas and Nagata (1979) and Hoitink and Boenm (1999) support the idea that the high organic matter content had little adverse effect on $P$. cinnamomi and, in fact, the pathogen can even benefit from an increase in organic matter due to its saprotrophic nature. Notwithstanding that this explanation may be feasible, we also considered the hypothesis that the correlation between the interaction term $\mathrm{OM} \times \mathrm{MA}$ and the disease occurrence is not a cause-effect relationship. In the study area farmers add copious amounts of manure after visual detection of chestnut tree decline and the undecomposed fresh manure around a tree could act as a suitable substrate for $P$. cinnamomi infection. It is well known that correlation does not imply causality, thus we must be aware that the appearance of first symptoms could be related to an increase of the organic matter content following manuring. Manuring may not be a factor that directly contributes to the ink disease. Additional data collection and further work is needed to determine the correct explanation.

The logistic model was ideally suited to classify the chestnut groves as diseased or nondiseased ( $94 \%$ of cases classified correctly). Although this study is based on observational, not experimental, data, we suggest that the identified potential cause-effect hypothesis, namely the 'soil compaction' to 'stand health' relationship, should be taken into account for effective management of this valuable crop in the study area and in other similar farming systems to reduce the risk of ink disease by minimizing this edaphic factor.

\section{Résumé \\ Compaction du sol et maladie de l'encre du châtaignier}

La maladie de l'encre du châtaignier, causée par l'oomycète Phytophthora cinnamomi, pathogène du sol ayant une distribution mondiale, est la cause des principaux problèmes sanitaires des châtaigniers au Portugal, limitant la production dans de nombreux peuplements et l'établissement de plantations dans de nouvelles zones. Une enquête a été menée dans 32 peuplements de châtaigniers des Montagnes Padrela, dans le nord du Portugal, pour étudier la relation entre maladie de l'encre, facteurs édaphiques et pratiques de gestion. La régression logistique a été utilisée pour analyser les effets des variables liées au sol et aux pratiques de gestion sur le statut sanitaire des peuplements. Il en résulte que les principaux facteurs affectant la maladie sont la compaction du sol (COMP), le niveau de matière organique du sol $(\mathrm{OM})$ et les pratiques de fertilisation organique (MA). Un modèle logistique comprenant la variable COMP et l'interaction OMxMA prédit correctement le statut sanitaire du peuplement dans $94 \%$ des cas, soit 30 sur 32 des parcelles étudiées. Les coefficients de la fonction logistique indiquent que la probabilité pour un peuplement d'être atteint par la maladie de l'encre augmente avec la compaction du sol et le niveau de matière organique dans les peuplements où la fertilisation organique est une pratique courante. 


\section{Zusammenfassung \\ Bodenverdichtung und Tintenkrankheit}

Der Oomyzet Phytophthora cinnamomi ist ein bodenbürtiges Pathogen mit weltweiter Verbreitung. Es ist für die Mehrheit der Erkrankungen von Edelkastanien in Portugal verantwortlich. Der Pilz reduziert den Ertrag in vielen Beständen und verunmöglicht die Bestandesgründung. In 32 Beständen von Edelkastanien in den Padrela-Bergen im Norden Portugals wurden die Zusammenhänge zwischen dem Vorkommen der Tintenkrankheit, edaphischen Faktoren und Bewirtschaftungsformen untersucht. Die Auswirkungen von Bodenfaktoren und Bewirtschaftungsformen auf den Gesundheitszustand der Bestände wurden mittels einer logistischen Regression analysiert. Verantwortlich für das Auftreten der Krankheit waren hauptsächlich die Bodenverdichtung, der Anteil an organischem Material im Boden und das Ausbringen von Jauche. Das logistische Model mit der Bodenverdichtung und der Interaktion zwischen dem Anteil an organischem Material im Boden und dem Ausbringen von Jauche als unabhängige Variabeln erlaubte die beste Vorhersage des Gesundheitszustandes der Bestände. Für $94 \%$ oder 30 der 32 Bestände war die Vorhersage des Gesundheitszustandes korrekt. Die Regressionskoeffizienten zeigten, dass die Wahrscheinlichkeit für das Vorkommen der Krankheit in einem Bestand mit zunehmender Bodenverdichtung und zunehmendem Anteil organischen Materials in gejauchten Beständen zunimmt.

\section{References}

Abreu, C. G., 1996: Doença da tinta: causas e consequências do declínio do castanhal. Estudos Transmontanos 6, 269-289.

Abreu, C. G.; Coutinho, J. F.; Cardooso, A. O.; Campos, A. C., 1993: Suppressive soils and chestnut ink disease. In: Proc. Int. Congress on Chestnut, Spoleto, Italy. October, 20-23, 1993. Ed. by Antognozzi, E. Spoleto: University of Perugia and Comunità Montana Monti Martani e Serano, pp. 533-536.

Abreu, C. G.; Martins, L. M.; Cardoso, A.; Borges, O.; Carvallho, L.; Gouveia, E., 1999: Chestnut ink disease. An integrated approach to its control. In: NATO/ Science for Stability Programme, Final Report PO-931275. Ed. by Aвreu, C. Vila Real: UTAD, pp. 43-53.

AnAgnostakis, S. L., 1995: The pathogens and pests of chestnuts. In: Advances in Botanical Research. Ed. by Andrews, J.H.; Tommerup, I. New York: Academic Press, pp. 125-145.

Bengough, A. G.; Mullins, C. E., 1990: Mechanical impedance to root growth: a review of experimental techniques and root growth responses. J. Soil Sci. 41, 341-358.

BODET, L., 2001: The international chestnut marketing situation: a summary of the literature and existing data. Lexington, KY: University of Kentucky Department of Agricultural Economics. Available from: http://www.uky.edu/ag/agecon/publications/staff411.pdf.

Bounous, G., 2002: Il castagno. Coltura, ambiente ed utilizzazioni in Italia e nel mondo. Bologna: Edagricole, pp. 311.

Branzanti, M. B.; Rocca, E.; Pisi, A. M., 1998: Biological control of chestnut ink disease with ectomycorrhizal fungi. Abstract from 2nd Int. Conf. on Mycorrhiza, Uppsala, Sweden, July 5-10, 1998. Available from: http://www.icom2.slu.se/abstracts/branzanti1.html.

Brasier, C. M., 1996: Phytophthora cinnamomi and oak decline in southern Europe. Environmental constraints including climate change. Ann. Sci. For. 53, 347-358.

Brasier, C. M.; Robredo, F.; Ferraz, J. P., 1993: Evidence for Phytophthora cinnamomi involvement in Iberian oak decline. Plant Pathol. 42, 140-145.

Cadahia, D.; Cobos, J.; Soria, S.; Clauser, F.; Gellini, R.; Grossoni, P.; Ferreira, M., 1991: Observação de danos em espécies florestais mediterrâneas. Madrid: Comissão Comunidade Europeia.

Castello, J. D.; Leopold, D. J.; Smallidge, P. J., 1995: Pathogens, patterns, and processes in forest ecosystems. Bioscience 45, 16-32.

Coffey, M. D., 1987: Phytophthora root rot of avocado an integrated approach to control in California. Plant Dis. 71, 1046-1052.

Craddock, J. H.; Bassi, G., 1999: Effect of clonally propagated interspecific hybrid chestnut rootstocks on short-term graft incompatibility with four cultivars of Italian 'Marrone'. Acta Hort. 494, 207-212.

Hoiтink, H. A.; Bоенм, M. J., 1999: Biocontrol within the context of soil microbial communities: a substrate-dependent phenomenon. Ann. Rev. Phytopat. 37, 427-446.

Hosmer, D. W., Jr.; Lemeshow, S., 1989: Applied Logistic Regression. New York: John Wiley and Sons. 
Kliejunas, J. T.; Nagata, J. T., 1979: Phytophthora cinnamomi in Hawaiian forest soils: seasonal variations in population levels. Phytopathology 69, 1268-1272.

Marks, G.; Kassaby, F.; Reynolds, S., 1972: Die-back in the mixed hardwood forests of Eastern Victoria: a preliminary report. Aust. J. Bot. 20, 141-154.

Martins, L. M.; Oliveira, M. T.; Abreu, C. G., 1999: Soils and climatic characteristics of chestnut stands that differ on the presence of ink disease. Acta Hort. 494, 447-449.

Myers, R. H., 1990: Classical and Modern Regression with Applications. Belmont, CA: Duxbury Press.

Nagelkerke, N. J. D., 1991: A note on a general definition of the coefficient of determination. Biometrika 78, 691-692.

Neter, J.; Kutner, M. H.; Nachtsheim, C. J.; Wasserman, W., 1996: Applied Linear Regression Models, 3rd edn. Homewood, IL: Irwin.

Pimentel, A. L., 1947: Phytophthora cinnamomi, another extremely virulent agent of the chestnut ink disease. Agronomia Lusitana 9, 181-191.

Portela, E.; Aranha, J.; Martins, A.; Pires, A.L., 1999: Soil factors, farmer's practices and chestnut ink disease: some interactions. Acta Hort. 494, 433-442.

Portela, E. O.; Roboredo, M. O.; Louzada, J., 2003: Assessment and description of magnesium deficiencies in chestnut groves. J. Plant Nutr. 26, 503-523.

SAS InstituTe Inc., 1999: SAS/STAT User's Guide, Version 8. Cary, NC: SAS Institute Inc.

Tsao, P.; Ocana, G., 1969: Selective isolation of species of Phytophthora from natural soils on an improved antibiotic medium. Nature 223, 636-638.

Utad-Dratm, 1999: Recomendações para a instalação e condução de soutos. Mirandela: Marsoni, pp. 17.

Weste, G., 1984: Damage and loss by Phytophthora species in forest crops. In: Plant Diseases: Infection, Damage and Loss. Ed. by Wood, F.; Jellis, G. Oxford: Blackwell Scientific Publications, pp. 273-284.

YARHAM, D., 1988: The contribution and value of cultural practices to control arable crop diseases. In: Control of Plant Diseases: Costs and Benefits. Ed. by Clifford, B.; Lester, E. Oxford: Blackwell Scientific Publications, pp. 135-154.

Zentmyer, G. A., 1980: Phytophthora cinnamomi and the Diseases it Causes. St. Paul, MN: American Phytopathological Society, Monograph No. 10, pp. 96. 